\title{
BIOSYNTHESIS OF $\triangle$-AMINOLEVULINATE IN GREENING BARLEY LEAVES II: INDUCTION OF ENZYME SYNTHESIS BY LIGHT
}

\author{
by
}

\author{
C. GAMINI KANNANGARA and SIMON P. GOUGH
}

Department of Physiology, Carlsberg Laboratory

Gamle Carlsberg Vej 10, DK-2500 Copenhagen Valby

Keywords: Chloroplast, etioplast, glutamate-l-semialdehyde aminotransferase

The $\delta$-aminolevulinate synthesizing enzyme is found in significant quantities in the stroma of barley etioplasts. The amount of the enzyme per seedling increases at least three-fold during the first 12 hours of greening in six day old dark-grown seedlings. In etiolated leaves illuminated for two hours and then returned to darkness for up to ten hours, the $\delta$-aminolevulinate synthesizing activity increases in the same way as the activity in leaves greening in continuous light. Previous hypotheses to explain the regulation of $\delta$-aminolevulinate and protochlorophyllide synthesis with a rapid turn-over of the $\delta$-aminolevulinate synthesizing enzyme are excluded by this observation. Cycloheximide inhibits the induction of the $\delta$-aminolevulinate synthesizing enzyme caused by light, and also the synthesis of the enzyme between six and twelve hours of greening. Feeding etiolated barley leaves with 35S-methionine during the first six hours of greening results in a prominantly labelled polypeptide with an approximate molecular weight of 67,000 daltons. This polypeptide is $c 0$-purified with $\delta$-aminolevulinate synthesizing activity by Bio-gel column fractionation and with glutamate-1-semialdehyde aminotransferase by DEAE-Sephadex column chromatography.

\section{INTRODUCTION}

With the exception of gymnosperm cotyledons continuous illumination is required for chlorophyll formation in higher plants. It is generally agreed that the pathway of chlorophyll synthesis is regulated at the step of $\delta$-aminolevulinate formation $(3,8,9,20,25,27,29,30)$. The evidence is extensive that in the dark $\delta$ aminolevulinate synthesis is limiting for the synthesis of $\mathrm{Mg}$-porphyrins in leaves $(12,15$, $21,25,26,31,34)$. Studies using inhibitors indicate that protein synthesis is required for producing nonlimiting amounts of $\delta$-aminolevulinate for chlorophyll formation in dark-grown seedlings $(10,21,25)$. A protein with a deduced half-life of about $1 \frac{1}{2}$ hours in barley and 80 minutes in maize has been implicated in the regulation of $\delta$-aminolevulinate formation in greening leaves $(9,25)$. The estimates of enzyme levels in these studies were made indirectly by measuring the accumulation of $\delta$-aminolevulinate in the presence of levulinate $(2,9)$ or the accumulation of chlorophyll in the presence of the protein synthesis inhibitor cycloheximide (25). A direct in vitro assay for the $\delta$ aminolevulinate synthesizing enzyme or enzyme complex is now available $(11,19)$. We have examined to what extent previous conclusions on 
the regulation of $\delta$-aminolevulinate biosynthesis can be verified by measuring the activities of the isolated enzyme during greening of dark-grown leaves. In this paper we report on the presence of the $\delta$-aminolevulinate synthesizing enzyme in barley etioplasts and on the induction of the synthesis of the enzyme by light.

\section{MATERIALS AND METHODS}

\subsection{Plant Material}

Seeds of the two cultivars Svalov's Bonus and Marie (the matura- $a^{8}$ mutant from Bonus) were germinated on moist vermiculite and grown in complete darkness for six days. During seedling growth the temperature was maintained between 20 and $23^{\circ} \mathrm{C}$ and relative humidity around $70 \%$. The dark-grown seedlings were greened with white light provided by a bank of six „Osram-L-Fluora" fluorescent tubes $(20 \mathrm{~W})$ placed $45 \mathrm{~cm}$ from the top of the seedlings.

\subsection{Chemicals}

L-glutamate-U- ${ }^{14} \mathrm{C}$ with a specific activity of $290 \mathrm{mCi} \cdot \mathrm{mmole}^{-1}$ and ${ }^{35} \mathrm{~S}-$ methionine with an approximate specific activity of $900 \mathrm{Ci} \cdot \mathrm{mmole}^{-1}$ was obtained from Radiochemical Centre, Amersham, U.K. N-carbobenzoxy L-glutamate- $\gamma$-benzyl ester was obtained from Bachem, Bubendorf, Switzerland. Anti-ribulose-1,5-bisphosphate carboxylase was a gift from cand. scient. Carsten Poulsen.

\subsection{Plastid isolation and preparation of stroma protein}

Leaves were harvested, wrapped in aluminium foil and cooled on ice. Approximately 60 to $80 \mathrm{~g}$ fresh weight of cooled leaves was placed in a precooled homogenizer fitted with razor blades (17) containing $200 \mathrm{ml}$ of ice-cold grinding medium and homogenized for about one minute. The grinding medium contained $0.6 \mathrm{M}$-glycerol and $0.1 \mathrm{~m}$-Tricine- $\mathrm{NaOH}$, pH 7.9 The homogenate was squeezed through a single layer of nylon gauze $(31 \mu \mathrm{mesh})$ and filtered through another layer of nylon gauze. The filtrate was centrifuged in a Sorval RC-2B centrifuge at 1500 $\mathrm{g}$ for 5 minutes at $4^{\circ} \mathrm{C}$. The pellet of plastids was suspended in $6 \mathrm{ml}$ of medium containing 0.3 M-glycerol, 0.1 м-Tricine- $\mathrm{NaOH}, \mathrm{pH} 7.9,1 \mathrm{~mm}$ dithiothreitol and $1 \mathrm{~mm}-\mathrm{MgCl}_{2}$. The plastids were disrupted by passing the suspension through an ice-cold French pressure cell at 4,000 p.s.i. The disrupted plastid preparation was centrifuged at $226,000 \mathrm{~g}$ for 15 minutes at 0 to $4^{\circ} \mathrm{C}$ in a Beckman L5/75 ultracentrifuge using a Ti-50 rotor. Most of the membranes were pelleted at this centrifugal force and the supernatant obtained was referred to as the plastid stroma protein. The preparations from darkgrown plants were made in dim green light and the preparations from plants exposed to white light were handled in room light.

\subsection{Enzyme assays for $\delta$-aminolevulinate synthesis}

The synthesis of $\delta$-aminolevulinate in vitro was followed in either of two enzyme reaction mixtures, one catalyzing the conversion of $\mathrm{L}$ glutamate- $U-{ }^{14} \mathrm{C}$ into $\delta$-aminolevulinate and the other catalyzed the conversion of glutamate-1semialdehyde into $\delta$-aminolevulinate. The incubation mixture for the conversion of L-glutamate-U- ${ }^{14} \mathrm{C}$ into $\delta$-aminolevulinate contained in a total volume of $2.25 \mathrm{ml}$ the following ingredients in umoles: Glycerol, 600; Tricine- $\mathrm{NaOH}$ pH 7.9, 100; $\mathrm{MgCl}_{2}, 50 ;$ ATP, 1; NADPH, 2: dithiothreitol, 2; and in addition, 3 to $6 \mathrm{mg}$ plastid stroma protein and $2.5 \mu \mathrm{Ci}$ of $\mathrm{L}$ glutamate-U $-{ }^{4} \mathrm{C}$. The mixture was incubated for 15 minutes at $27^{\circ} \mathrm{C}$. The reaction was terminated by the addition of $100 \mu \mathrm{g}$ of $\delta$ aminolevulinic acid and $50 \mu$ l of $70 \%$ perchlorid acid. The incorporation of label into $\delta$-aminolevulinate was determined as described previously (11). The incubation mixture for glutamate-1semialdehyde aminotransferase contained in 1.1 $\mathrm{ml}$ the following ingredients in $\mu$ moles: Glycerol, 300; Tricine- $\mathrm{NaOH}$ pH 7.9, 100; glutamate- 1 -semialdehyde, 1 and 50 to $100 \mu \mathrm{g}$ of plastid stroma protein. The mixture was incubated for 15 minutes at $27^{\circ} \mathrm{C}$ and the reaction was stopped by the addition of $50 \mu \mathrm{l}$ of $70 \%$ perchloric acid. The precipitated protein was removed by centrifugation and the amount of $\delta$ aminolevulinate present in the supernatant was determined after converting the $\delta$-aminolevuli- 
nate into a pyrrole using ethyl acetoacetate. The details of this procedure have been described previously (24).

\section{5. ${ }^{35} \mathrm{~S}-$ Methionine incorporation into plastid stroma proteins}

Leaves from six-day dark-grown barley seedlings were harvested in dim green light. A centimeter from the tip of the leaves was cut off and a clean cut was made at the base of the leaf to give a middle segment approximately $6 \mathrm{~cm}$ in length. These segments (ca. $4 \mathrm{~g}$ fresh weight) were placed upright in a $10 \mathrm{ml}$ beaker containing $1 \mathrm{ml}$ of labelled methionine in water. A total of $20 \mathrm{~g}$ fresh weight of leaves was used with $5 \mathrm{ml}$ of water containing $300 \mu \mathrm{Ci}$ of ${ }^{35} \mathrm{~S}$-methionine. The beakers were then placed under »OsramFluora« fluorescent light with a small fan moving air over the leaves. After 3 hours, most of the radioactive solution was taken up by the leaves and $0.8 \mathrm{ml}$ of water was added to the beakers. After 6 hours in light the ${ }^{35} \mathrm{~S}$ methionine fed leaves were mixed with untreated barley leaves greened for 6 hours and plastids were isolated and stroma proteins prepared as described in section 2.3 .

\subsection{Cycloheximide and chloramphenicol treatment}

Leaves ( $75 \mathrm{~g}$ fresh weight) were placed in a litre of the required solution contained in a two litre Büchned flask. Suction was applied to the flask using a water aspirator. The flask was periodically shaken and the vacuum released. This process was repeated untill the leaves sank into the liquid. After infiltration the leaves were removed from the solutions and placed on moist filter paper.

\subsection{Other methods}

Protein was measured according to the method of Lowry et al. (22). Chlorophyll determinations were made after extracting the pigments into $80 \%$ acetone either by the method of BRUINSMa (5) or ANDERSON and BOARDMAN (1). Optimal density was measured in a Zeiss PMQ 3 spectrophotometer. Glutamate-1-semial- dehyde was prepared as described previously (19). Radioactivity was measured in a Beckman Liquid Scintillation System with Dimilume-30 as the scintillation fluid.

\section{RESULTS}

\subsection{Chlorophyll formation and changes in} the $\delta$-aminolevulinate synthesizing activity of plastid stroma protein

Figure 1a illustrates the accumulation of chlorophyll in the primary leaves of six-day old barley seedlings (cv. Marie) grown in complete darkness and placed in white light under the conditions used in this investigation. The leaves of dark-grown seedlings contained only protochlorophyllide (ca. $10 \mu \mathrm{g} \cdot \mathrm{g}^{-1}$ fresh weight). When these dark-grown leaves were exposed to light ca. $6 \mu \mathrm{g}$ of chlorophyll per $\mathrm{g}$ fresh weight was formed from the pre-existing protochlorophyllide. Thereafter in continuous light de novo synthesis of chlorophyll began and the leaves rapidly accumulated chlorophyll. Seedlings exposed to light for two hours ceased to make new chlorophyll when returned to darkness and showed no reduction in chlorophyll content during the next 28 hours in darkness. The results of parallel measurements on the ability of the plastid stroma protein to convert L-glutamate$\mathrm{U} .{ }^{4} \mathrm{C}$ into $\delta$-aminolevulinate are given in Figure $1 b$. The six-day old etiolated barley leaves of this experiment gave a stroma protein preparation which incorporated about $18,000 \mathrm{cpm}$ of $\mathrm{L}$ glutamate-U $-{ }^{14} \mathrm{C}$ into $\delta$-aminolevulinate per $\mathrm{g}$ fresh weight of leaves under the conditions of the assay. The $\delta$-aminolevulinate synthesizing activity increased upon illumination of dark-grown barley seedlings (Figure 1b). This increase occurred without a lag and reached after 12 hours of illumination approximately five times the level present in the dark-grown seedlings. Both the activity measurable in dark-grown seedlings and the time course of the increase of the level of activity varied considerably among different batches of leaves (e.g. Tables I and II). At some time between 12 and 30 hours of greening, the $\delta$-aminolevulinate synthesizing activity declined. In etiolated barley leaves illuminated for two hours and then returned to darkness for up to ten hours, the $\delta$-aminolevulinate synthesizing activity increased in the same 

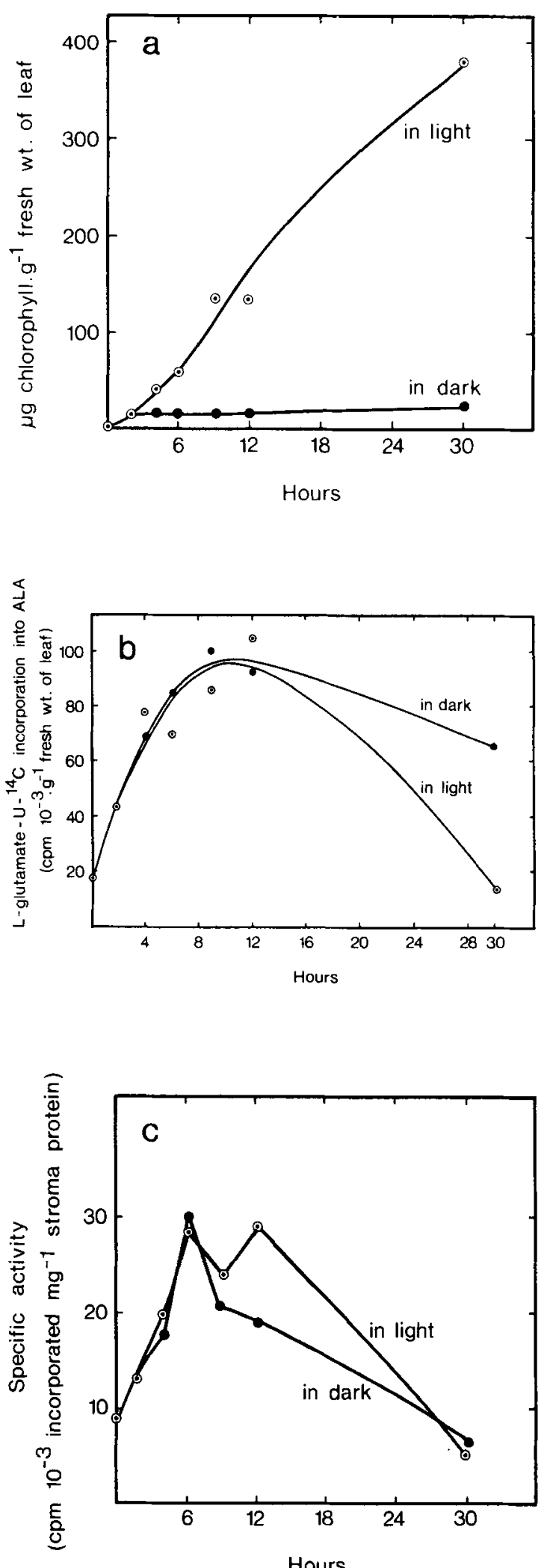

Figure 1. The effect of light on the formation of chlorophyll and $\delta$-aminolevulinate synthesizing activity in dark-grown barley leaves. Six-day-old barley (cv. Marie) seedlings grown in complete darkness were placed in white light. Some of the seedlings were returned to darkness after a period of two hours in light. Leaves were harvested and analyzed from the seedlings at 0 (etiolated leaves), 2, 4, 6, 9, 12 and 30 hours. Five leaves were used for determination of chlorophyll content per $g$ fresh weight of leaf (a) and $65 \mathrm{~g}$ fresh weight of leaves were used for isolation of plastid stroma. The formation of $14 \mathrm{C}$ - $\delta$-aminolevulinate from l-glutamate- $\mathrm{u}-14 \mathrm{C}$ was measured in $2 \mathrm{ml}$ stroma preparations and expressed on a fresh weight basis (b). This was obtained by dividing the enzyme activity in the $2 \mathrm{ml}$ stroma preparation by the chlorophyll content in $2 \mathrm{ml}$ of disrupted plastid preparation and multiplying the value with the chlorophyll content in one $\mathrm{g}$ fresh weight. The specific activity of the enzyme is given in (c) and was determined as radioactive $\delta$-aminolevulinate formed per $\mathrm{mg}$ protein in $2 \mathrm{ml}$ stroma preparation.

way as the activity in leaves greening in continuous light (Fig. Ib). Also in these preilluminated leaves the enzyme activity per $g$ fresh weight of leaves decreased upon reaching a maximum after 10 hours in darkness, but the decrease was less drastic than in the continuously illuminated leaves. The low value in the latter after 30 hours of greening is possibly due to a decreased yield of intact plastids in this preparation and thus an underestimation of enzyme activity.

The changes in specific activity of the $\delta$ aminolevulinate synthesizing enzyme, expressed as activity per $\mathrm{mg}$ of total plastid stroma protein, in greening barley leaves and in leaves returned to darkness after a two hours pre-illumination are given in Figure 1c. In both cases the specific activity increased about three-fold in 6 hours. After 12 hours the specific activity declined and reached at 30 hours approximately $60 \%$ of that found in the plastids of dark-grown leaves. Previous studies have shown that illumination of etiolated barley leaves causes an increase in several enzymes located in the plastids (14). In contrast to the aminolevulinate synthesizing activity, the major plastid stroma protein, ribulose-1,5-bisphoshate carboxylase increases only by 50 per cent of the dark level when five to seven day old dark-grown barley seedlings are 
greened for 6 hours (16). Therefore, the results in Figure $1 c$ reveal that during the first six hours of illumination, the $\delta$-aminolevulinate synthesizing enzyme is made faster than the major soluble plastid protein.

\subsection{Incorporation of $35 \mathrm{~S}$-methionine into plastid stroma proteins}

From the results given above, the incorporation of a radioactive amino acid into protein in vivo during the first six hours of greening in etiolated barley leaves is expected to label the $\delta$ aminolevulinate synthesizing enzyme preferentially among the proteins present in the plastid stroma. To test this, stroma proteins of plastids from ${ }^{35} \mathrm{~S}$-methionine fed leaves were prepared as described in section 2.5. and fractionated on a Bio-gel column as described previously (19). In the column eluate there were two peaks of radioactivity (Fig. 2). The first peak corresponding to the volume of the column contained proteins with molecular weights above 500,000 dalton. The second peak of radioactivity was associated with the column fractions previously

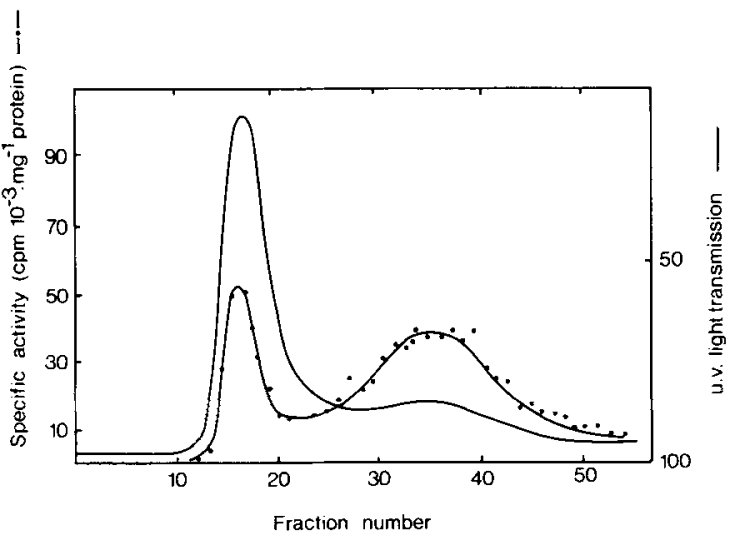

Figure 2. Fractionation of $35 \mathrm{~S}$-methionine labelled plastid stroma proteins of greening barley. ${ }^{35 \mathrm{~S}-}$ methionine was fed to detached leaves from six-dayold dark-grown barley (cv. Bonus) seedlings as given in section 2.5. Plastid stroma proteins obtained from these leaves were loaded on to a Bio-gel A 0.5 column ( 5 times $36 \mathrm{~cm}$ ) and eluted with an aqueous solution containing $0.3 \mathrm{~m}$-glycerol, $0.1 \mathrm{~m}$-Tricine- $\mathrm{NaOH}, \mathrm{pH}$ $7.9,1 \mathrm{~mm}$-dithiothreitol and $1 \mathrm{~mm}-\mathrm{MgCl}_{2}$. The eluate was scanned for ultraviolet light absorption and fractions $(8 \mathrm{ml})$ were collected. Protein was determined in a $50 \mu \mathrm{l}$ aliquot and radioactivity in a $500 \mu \mathrm{l}$ aliquot of each fraction. found to contain $\delta$-aminolevulinate synthesizing activity (19). Immunoprecipitation using a rabbit antibody against barley ribulose-1,5-bisphos-

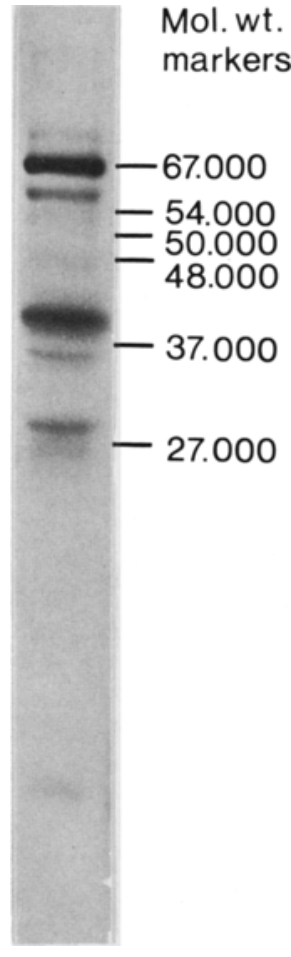

Fig. 3

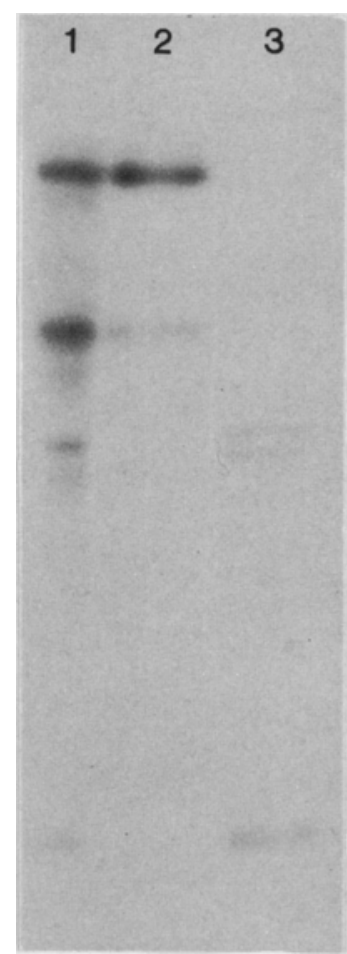

Fig. 5
Figure 3. The pattern of $35 \mathrm{~S}$-methionine labelled polypeptides eluting from the Bio-gel column with a fraction known to contain $\delta$-aminolevulinate synthesizing activity. The protein fraction No. 35 from the experiment given in Figure 2 was precipitated with $5 \%$ trichloroacetic acid. The precipitate was dissolved in $45 \mu \mathrm{l}$ of $0.1 \mathrm{MTris}$ (hydroxymethyl) aminomethane containing $2.5 \%$ sodium dodecyl sulphate and 0.25 M-dithiothreitol, boiled in a water bath for one minute and subjected to electrophoresis. 2.5-diphenyloxazol (PPO) was introduced into the gel and the gel dried as described in (4). The dried gel was exposed to RP Royal X-Omat film (Kodak) for two days and then developed.

Figure 5. Labelled polypeptides associated with the two radioactive peaks from the DEAE-Sephadex column. Analyses were performed as given for Figure 3. Track 1 contains the fraction analyzed in Figure 3 for reference. Track 2 contains the polypeptides eluted with the second radioactivity peak from the DEAE-Sephadex column while track 3 contains the polypeptides eluted with the first radioactivity peak from the same column. 


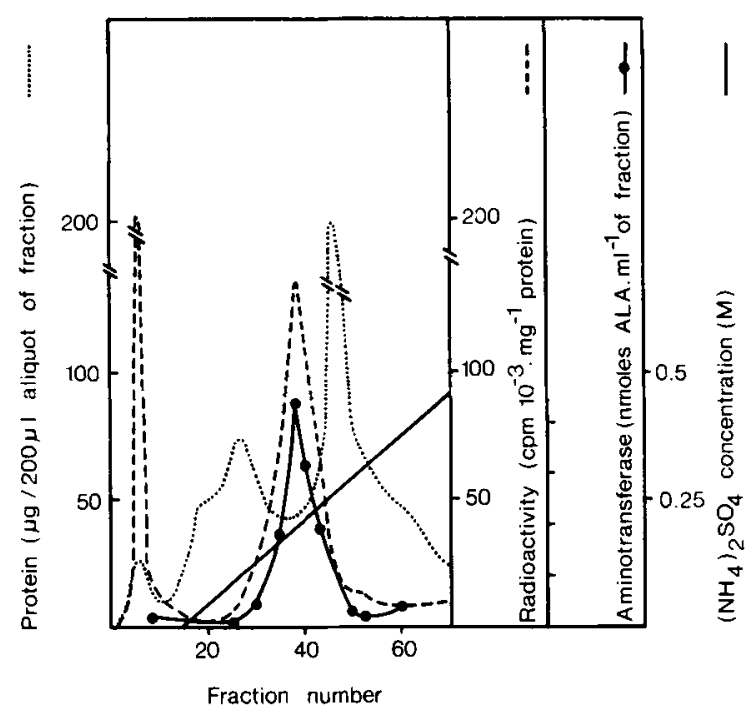

Figure 4. DEAE-Sephadex fractionation of the radioactive proteins eluted from the Bio-gel column with the fractions known to contain $\delta$-aminolevulinate synthesizing activity. The fractions (Nos. 24 to 46) corresponding to the second radioactivity peak in the Bio-gel column fractionation given in Figure 2 were pooled, concentrated by pressure dialysis and applied to a DEAE-Sephadex A-25 column ( 2.5 times $11 \mathrm{~cm}$ ). The column was washed with $80 \mathrm{ml}$ of solution containing $0.3 \mathrm{M}$-glycerol, $0.1 \mathrm{M}$-Tricine$\mathrm{NaOH} \mathrm{pH} 7.9$, I mm-dithiothreitol and $1 \mathrm{~mm}-$ $\mathrm{MgCl}_{2}$. A linear gradient of $\left(\mathrm{NH}_{4}\right)_{2} \mathrm{SO}_{4}$ dissolved in the above medium was then applied to the column. The eluate was collected in $8 \mathrm{ml}$ fractions and aliquots of the fractions were used for protein and radioactivity determinations. One $\mathrm{ml}$ aliquots of the fractions were filtered through small Sephadex G-25 columns ( $\left(1\right.$ times $5 \mathrm{~cm}$ ) to remove the $\left(\mathrm{NH}_{4}\right)_{2} \mathrm{SO}_{4}$ and assayed for glutamate-1-semialdehyde aminotransferase. $\mathrm{ALA}=\delta$-aminolevulinate.

phate carboxylase revealed that about $20 \%$ of the label in the first peak was associated with this major chloroplast stroma protein. Centrifugation of the first peak fraction for 45 minutes at $226,000 \mathrm{~g}$ at $0^{\circ} \mathrm{C}$ gave a green pellet containing $83 \%$ of the radioactivity. A prominently labelled polypeptide was observed among the labelled polypeptides when the second radioactivity peak fraction from the Bio-gel column in Figure 2 was analyzed by sodium dodecyl sulphate-polyacrylamide gel electrophoresis (Fig. 3). This polypeptide had an apparent molecular weight of 67,000 daltons. Figure 4 illustrates further fractionation of the labelled proteins eluting with the $\delta$ aminolevulinate synthesizing enzyme in the Biogel column. DEAE-Sephadex column chromatography separated these proteins into four peaks while the radioactivity was separated into two peaks. The glutamate-1-semialdehyde aminotransferase eluted as a single peak in the fractions corresponding to the second radioactivity peak in this column, but after DEAE-Sephadex chromatography none of the peak fractions had detectable enzyme activity capable of converting Lglutamate-U-14C into $\delta$-aminolevulinate. Sodium dodecyl sulphate-polyacrylaminde gel electrophoresis of the proteins in the two radioactivity peak fractions of the DEAESephadex fractionation is given in Figure 5. It is evident that the 67,000 dalton polypeptide was eluted together with the activity for glutamate-1semialdehyde into $\delta$-aminolevulinate which is considered one of the reactions catalyzed by the $\delta$-aminolevulinate synthesizing enzyme in barley $(19,20)$. Therefore it is concluded that the increase of $\delta$-aminolevulinate synthesizing activity during the early stages of greening is correlated with the formation of a 67,000 dalton polypeptide in the plastid stroma. Furthermore this polypeptide and another labelled polypeptide with lower molecular weight (cf. Figure 5) copurifies with the $\delta$-aminolevulinate synthesizing enzyme in the two different columns.

\subsection{The effect of cycloheximide and chloram- phenicol on the formation of $\delta$-aminole- vulinate synthesizing enzyme at two stages of plastid development}

Tables I and II illustrate the effects of cycloheximide, an inhibitor of protein synthesis on cytoplasmic ribosomes, and chloramphenicol, an inhibitor of protein synthesis on chloroplastic ribosomes, on the formation of the $\delta$-aminolevulinate synthesizing enzyme in dark-grown leaves exposed to light and in rapidly greening leaves. The infiltration of leaves with water alone gave a reduction in the $\delta$-aminolevulinate synthesizing activity associated with the plastid stroma protein when analyzed in the in vitro assay. This is paralleled by the inhibitory effect of water infiltration on chlorophyll accumulation in light 
Table I.

The effect of cycloheximide and chloramphenicol on the formation of $\delta$-aminolevulinate synthesizing activity upon illumination of etiolated barley leaves. For each treatment $65 \mathrm{~g}$ fresh weight of leaves from six-day old dark grown barley (cv. Marie) seedlings were used. The concentration of the inhibitors used was 100 $\mu \mathrm{g} \cdot \mathrm{ml}^{-1}$. Stroma proteins obtained from isolated plastids were used in the enzyme assay.

\begin{tabular}{lc}
\hline Treatment & $\begin{array}{c}\text { L-glutamate-U-14C incorporation } \\
\text { into } \delta \text {-aminolevulinate } \\
\text { (cpm-mg protein-1) }\end{array}$ \\
\hline $\begin{array}{l}\text { 1. Dark-grown leaves } \\
\text { 2. Leaves greened 6 hours }\end{array}$ & 6956 \\
$\begin{array}{l}\text { 3. Dark-grown infiltrated with } \\
\text { water and greened for 6 hours } \\
\text { 4. Dark-grown leaves infiltrated with } \\
\text { chloramphenicol and greened for 6 hours }\end{array}$ & 28682 \\
$\begin{array}{l}\text { 5. Dark-grown leaves infiltrated with } \\
\text { cycloheximide and greened for 6 hours }\end{array}$ & 18521 \\
\hline
\end{tabular}

\section{Table II.}

The effect of cycloheximide and chloramphenicol on $\delta$-aminolevulinate synthesizing activity in barley leaves after 6 hours of greening. For each treatment $75 \mathrm{~g}$ fresh weight of leaves from six-day old dark-grown barley (cv. Bonus) seedlings were used. The concentration of the inhibitors used was $100 \mu \mathrm{g} \cdot \mathrm{ml}^{-1}$. Stroma proteins obtained from isolated plastids were used in the enzyme assay.

Treatment of dark-grown leaves:

\begin{tabular}{cccc}
$\begin{array}{c}\text { greened } \\
\mathrm{h}\end{array}$ & $\begin{array}{c}\text { infiltrated } \\
\text { with }\end{array}$ & $\begin{array}{c}\text { additional } \\
\text { illumination } \\
\mathrm{h}\end{array}$ & $\begin{array}{c}\text { l-glutamate-U-14C incorporation } \\
\text { into } \delta \text {-aminolevulinate } \\
\text { (cpm.mg protein-1) }\end{array}$ \\
\hline 0 & - & 0 & 10246 \\
6 & - & 0 & 13773 \\
6 & - & 6 & 20100 \\
6 & water & 6 & 17303 \\
6 & chloramphenicol & 6 & 15534 \\
6 & cycloheximide & 6 & 9718 \\
\hline
\end{tabular}

as can be readily observed visually. This inhibition was more pronounced in etiolated water-infiltrated leaves placed in light (Table I) than in the rapidly greening leaves (Table II). Etiolated barley leaves infiltrated with a solution containing $100 \mu \mathrm{g} \cdot \mathrm{ml}^{-1}$ chloramphenicol and illuminated for six hours contained more enzyme activity than the dark-grown seedlings while leaves similarly treated with $100 \mu \mathrm{g} \cdot \mathrm{ml}^{-1}$ of cycloheximide contained the same amount of activity as the dark control (Table I). In contrast to chloramphenicol, cycloheximide is able to competely block the induction of $\delta$-aminolevulinate synthesizing activity in etiolated barley leaves. Dark-grown barley seedlings greened for six hours, infiltrated with the chloramphenicol solution and illuminated for an additional 6 hours, revealed an increase in $\delta$-aminolevulinate synthesizing activity, but the increase was only about 50 per cent of that obtained in water infiltrated leaves (Table II). An analogous treatment with cycloheximide did not result in an increase of enzyme activity. Instead a decrease from $13,700 \mathrm{cpm} \cdot \mathrm{mg}$ protein ${ }^{-1}$ before drug infiltration to $9,700 \mathrm{cpm} \cdot \mathrm{mg}$ protein ${ }^{-1}$ was found (Table II). The latter value corresponds to the level of the dark-grown plants in this experiment. 


\section{DISCUSSION}

The stroma proteins of barley etioplasts studied here incorporated significant quantities of L-glutamate- $\mathrm{U}-{ }^{14} \mathrm{C}$ into $\delta$-aminolevulinate. Compared to the activity reported previously (19) the values are several fold improved but the differential between the etioplast stroma and plastid stroma is smaller. The improvements are attributable to the removal of $\mathrm{Ca}\left(\mathrm{NO}_{3}\right)_{2}$ from the grinding medium and the modified procedure for preparing the stroma by eliminating the step of plastid washing and by shortening the time of ultracentrifugation. The reaction mixture contained increased amounts of NADPH and was incubated at a higher temperature of $27^{\circ} \mathrm{C}$.

The in vitro measurements of the activity of the $\delta$-aminolevulinate synthesizing enzyme presented in this paper clarify several conclusions about the control of the enzyme previously derived $(9,10,23,25,33)$ by studies of chlorophyll and $\delta$-aminolevulinate accumulation in vivo. It is verified directly that the synthesis of the enzyme is induced by light in dark-grown seedlings, but that this synthesis does not require continuous illumination. The rapid decline in the rate of $\delta$-aminolevulinate synthesis upon transfer of greening seedlings into the dark has been explained by postulating a short half-life of the $\delta$ aminolevulinate synthesizing enzyme $(9,25)$. Such hypotheses are excluded by the observed continuous accumulation of the $\delta$-aminolevulinate synthesizing enzyme over a 10 hours dark period after a 2 hours illumination. A remaining possibility to explain the short term decline of $\delta$ aminolevulinate synthesis in vivo seems to be reversible inactivation by feedback inhibitors (e.g. 10) and availability of effectors like ATP and NADPH $(11,18)$. The results also reveal that feedback inhibitors, if present on the enzyme in the dark, are effectively removed by the isolation procedure employed.

Chloramphenicol and cycloheximide have been used to determine the cellular site of synthesis of chloroplast proteins (32). Whereas cycloheximide specifically inhibits cytoplasmic ribosomes in vitro and chloraphemicol specifically plastid ribosomes in vitro, in vivo experiments rarely give entirely decisive results because of the close cooperation of the two systems in the cell as exemplified by the two subunits of ribulose-bisphospate carboxylase (7). Both drugs are known to inhibit chlorophyll accumulation as well as $\delta$-aminolevulinate accumulation in the presence of levulinate $(21,25,32)$, cycloheximide frequently being more efficient. Induction of $\delta$-aminolevulinate accumulation by a brief illumination in barley could be inhibited completely by cycloheximide but not by chloramphenicol (10). This is in agreement with the present finding in which cycloheximide completely blocked the induction of the $\delta$-aminolevulinate synthesizing enzyme (Table I), whereas chloramphenicol only gave partial inhibition. The results indicate that the $\delta$-aminolevulinate forming enzyme or part of it is synthesized on cytoplasmic ribosomes.

Application of the two inhibitors at later stages of greening in bean and maize seedlings caused less severe inhibition of $\delta$-aminolevulinate accumulation in the presence of levulinate than at early stages (21). In barley, transfer of the leaves after 2.5 hours of greening into darkness led to the decay of $\delta$-aminolevulinate accumulation in the presence of levulinate over a 4.5 hours period $(10)$. Reillumination at this point in the presence of cycloheximide resulted in a rapid reestablishment of a high rate of $\delta$-aminolevulinate accumulation and it was concluded that a large part of the observed decay in the $\delta$ aminolevulinate forming capacity was due to reversible inhibition of the enzyme concerned. This is in agreement with the stability of the enzyme observed in the dark (Figure 1). Chloramphenicol treatment after 6 hours of greening did reveal a moderate inhibitory effect on the synthesis of the enzyme during the following 6 hour period (Table II), whereas cycloheximide treatment did not permit any new synthesis. There is an indication that the level of the dark grown leaves was reached by this treatment signifying a break-down. The activity present, however, is much larger than would be expected for an enzyme with a half-life of one to two hours. Further studies are required, to determine whether the break-down is the result of natural turnover or the result of proteolysis elicited by preventing cytosolic protein synthesis.

There is a prominent formation of $\delta$-aminolevulinate synthesizing enzyme compared with the accumulation of other soluble plastid proteins during the initial six hours of greening in darkgrown barley seedlings (Fig. Ic). The incorpora- 
tion of ${ }^{35 S-m e t h i o n i n e ~ t o ~ l e a v e s ~ d u r i n g ~ t h i s ~}$ period labels preferentially a 67,000 dalton polypeptide. Experiments will be carried out in the future to determine whether this polypeptide is a component of the $\delta$-aminolevulinate synthesizing enzyme of barley.

\section{ACKNOWLEDGEMENTS}

The authors are most grateful to Dr. JOHN INGVERSEN for performing the sodium dodecyl sulphate-polyacrylamide gel electrophoresis and fluorography of the ${ }^{35} \mathrm{~S}$-methionine labelled proteins. We thank Ms. Susanne Placing for skilled technical assistance, Ms. NINA RaSMUSSEN for drawing the figures, Ms. ANN-Sofi SteinHOLTZ for photography and Ms. INGE Sommer for typing the manuscript. We thank Professor DITER VON WETTSTEIN for his help and criticism.

\section{REFERENCES}

1. Anderson, J. M. \& N. K. Boardman: Studies on greening of dark grown bean plants. II. Development of photochemical activity. Austr. J. Biol. Sci. 17, 93-101 (1964).

2. Beale, S. I. \& P. A. Castelfranco: The biosynthesis of $\delta$-aminolevulinic acid in higher plants. 1. Accumulation of $\delta$-aminolevulinic acid in greening plant tissues. Plant Physiol. 53, $291-$ 296 (1974)

3. Bogorad, L.: Chlorophyll biosynthesis. In: Chemistry and Biochemistry of Plant Pigments. Ed. T. W. Goodwin: 1, 64-148 (1976) New York, Acad. Press

4. Bonner, W. M. \& R. A. LASKEY: A film detection method for tritium labelled proteins and nucleic acids in polyacrylamide gels. Eur. J. Biochem. 46, 83-88 (1974)

5. Bruinsma, J.: A comment on the spectrophotometric determination of chlorophyll. Biochem. Biophys. Acta. 52, 576-578 (1961)

6. Castelfranco, P. A., P. M. Rich \& S. I. Beale: The abolition of the lag phase in greening cucumber cotyledons by $\delta$-aminolevulinic acid. Plant Physiol. 53, 615-618 (1974)

7. Chua, N.-H. \& G. W. Schmidi: In vitro synthesis, transport and assembly of ribulose-1,5-bisphosphate carboxylase subunits. Brookhaven Symposia in Biol., in press (1978)

8. EILIS, R., T. SPOONER \& R. YakUI.IS: Regulation of chlorophyll synthesis in the green alga Golenkinia. Plant Physiol. 55, 791-795 (1975)
9. Fiunhr, R., E., Harei; S. Ki.ein \& E. Mel.ler: Control of $\delta$-aminolevulinic acid and chlorophyll accumulation in greening maize leaves upon light dark transitions. Plant Physiol. 56, 497-501 (1975)

10. Gough, S. P.: Light stimulated $\delta$-aminolevulinate accumulation in levulinate treated barley seedlings. Carlsberg Res. Commun. 43, 497508 (1978)

11. Gough, S. P. \& C. G. Kannangara: Synthesis of $\delta$-aminolevulinate by a chloroplast stroma preparation from greening barley leaves. Carlsberg Res. Commun. 42, 459-464 (1977)

12. Granick, S.: Magnesium porphyrins formed in barley seedlings treated with delta-aminolevulinic acid. Plant Physiol. 34 suppl., xviii (1959)

13. Harel; E. \& S. Ki.EIN: Light dependent formation of $\delta$-aminolevulinic acid in etiolated leaves of higher plants. Biochem. Biophys. Res. Commun. 49, 364-370 (1972)

14. Huffaker, R. C., R. L. Obendorf, C. J. Keller \& G. E. KI.EINKORF: Effect of light intensity on photosynthetic carboxylase phase enzymes and chlorophyll synthesis in greening leaves of Hordeum vulgare L. Plant Physiol. 41, 913-918 (1966)

15. KaHN, A., N. Avivi-Bleiser \& D. von WetrsTEIN: Genetic regulation of chlorophyll synthesis analysed with double mutants in barley. In: Genetics and Biogenesis of Chloroplasts and Mitochondria. Ed. Th. Bücher, N. Neupert, W. Sebald, S. Werner, New York/North Holland, 119-131 (1976)

16. Kannangara, C. G.: The formation of ribulose diphosphate carboxylase protein during chloroplast development in barley. Plant Physiol. 44. 1533-1537 (1969)

17. Kannangara, C. G., S. P. Gough, B. Hansen, J. N. Rasmussen \& D. J. Simpson: A homogenizer with replaceable razor blades for bulk isolation of active barley plastids. Carlsberg Res. Commun. 42, 431-440 (1977)

18. Kannangara, C. G. \& S. P. Gough: Synthesis of $\delta$-aminolevulinic acid and chlorophyll by isolated chloroplasts. Carlsberg Res. Commun. 42, 441-458 (1977)

19. Kannangara, C. G. \& S. P. Gough: Biosynthesis of $\delta$-aminolevulinate in greening barley leaves: Glutamate- I-semialdehyde aminotransferase. Carlsberg Res. Commun. 43, 185-194 (1978)

20. Kannangara, C. G., S. P. Gough \& D. von WeTtSTEIN: Biosynthesis of $\delta$-aminolevulinate and chlorophyll and its genetic regulation. In: Development in Plant Biology 2. Chloroplast Development. Eds. G. Akoyunoglou and J. H. 
Argyroudi-Akoyunoglou. Elsevier/North Holland, 147-160 (1978)

21. Klein, S., E. Harel, E. Neeman, E. Katz \& E. Meller: Accumulation of $\delta$-aminolevulinic acid and its relation to chlorophyll synthesis and development of plastid structure in greening leaves. Plant Physiol. 56, 486-496 (1975)

22. Lowry, O. H., N. J. Rosenbrough, A. L. FarR \& R. J. Randall: Protein measurement with Folin-phenol reagent. J. Biol. Chem. 193, 265275 (1951)

23. Masoner, M. \& H. Kasemir: Control of chlorophyll synthesis by phytochrome. I. The effect of phytochrome on the formation of $\delta$ aminolevulinate in mustard seedlings. Planta $126,111-117(1975)$

24. Mauzerall, D. \& S. Granick: The occurence and determination of $\delta$-aminolevulinic acid and porphobilinogen in urine. J. Biol. Chem. 219435-466 (1956)

25. Nadler, K. \& S. Granick: Controls on chlorophyll synthesis in barley. Plant Physiol. 46, 240-246 (1970)

26. Ochiai, S. \& E. Hase: Studies on chlorophyll formation in Chlorella protothecoides. I. Enhancing effects of light and added $\delta$-aminolevulinic acid, and suppressive effect of glucose on chlorophyll formation. Plant Cell Physiol. 11, 663-673 (1970)

27. Oh-hama, T. \& H. Senger: The development of structure and function in chloroplasts of greening mutant of Scenedesmus. III. Biosynthesis of ס-aminolevulinic acid. Plant Cell Physiol. 16, 395-405 (1975)

28. Oh-hama, T. \& E. Hasse: Synthesis of $\delta$ aminolevulinic acid and chlorophyll during chloroplast formation in Chlorella protothecoides. Plant Cell Physiol. 16, 297-303 (1975)

29. Schneider, H. A. W.: Regulation der Chlorophyll Biosynthese. Licht und entwicklungsbedingte Aktivitätsänderungen von vier aufeinander folgenden Enzymen der Porphyrin und Chlorophyll Biosynthesekette. Z. Naturforsch. 28C, 45-58 (1973)

30. Schneider, H. A. W.: Enzyme capacities for chlorophyll biosynthesis. Activation and de novo synthesis of enzymes. Z. Naturforsch. 31C, 55$63(1976)$

31. Sisler, E. C. \& W. H. Klein: The effect of age and various chemicals on the lag phase of chlorophyll synthesis in dark grown bean seedlings. Physiologia Plant. 16, 315-322 (1963)

32. Smillie, R. M. \& N. Scotr: Organelle biosynthesis: The chloroplast. Progr. in Molec. Subcell. Biol. 1, 136-202 (1969)

33. Virgin, H. I.: Studies on the formation of protochlorophyll and chlorophyll a under varying light treatments. Physiologia Plant. 11, 347362 (1958)

34. von Wettstein, D., A. KahN, O. F. Nieisen \& S. P. Gough: Genetic regulation of chlorophyll synthesis analysed with mutants in barley. Science 184, 800-802 (1974) 